\title{
An analysis of foreign direct investment attractiveness of the Russian Far East by Porter's Diamond model
}

\author{
(C) 2019 2. Han-Sol Lee
}

Peoples' Friendship University of Russia, 6 Miklukho-Maklaya U1., Moscow 117198, Russia

\begin{abstract}
This paper is dedicated to measuring the Foreign direct investment (FDI) attractiveness of the Russian Far East. In 2012, the Russian Federation officially addressed the Turn to the East Policy through «Measures to Implement the Russian Federation Foreign Policy" to resolve the chronically underdeveloped economy of the Far Eastern district. The Far Eastern development entails an enormous budget from abroad considering the enormous magnitude of investments projects. However, despite the continuous increasing investment propensity in the Russian Far East, the result is not yet impressive. Thereby, the thorough analysis of the FDI attractiveness of the Far East should more to be conducted. To do that, in this study, we analyzed the FDI attractiveness of the Far East based on the Porter's Diamond model, comprised of the four endogenous factors - Production Factor, Demand Factor, Related and Supporting Industries, and Firm Strategy Structure and Rivalry-, and the two exogenous factors-chance, and government. Based on the analysis, we diagnosed that weak factor and demand conditions and ambiguous political will majorly hinder from accelerating the Turn to the East Policy. Thereby, we concluded that to achieve momentum of the policy by generating high efficiency of the policy mechanisms to induce FDI, the strong political will should be accompanied with investmentfavorable factor and demand conditions.
\end{abstract}

Keywords: foreign direct investment (FDI), Russia's turn to the East policy, Russian economy, Asia-Pacific economy, Eurasian economy, Porter's Diamond model

\section{Introduction}

In 2012, the Russian Federation addressed «Measures to Implement the Russian Federation Foreign Policy", and publicized the Turn to the East Policy aiming to develop the relatively underdeveloped Far Eastern and Siberian regions. However, the development of Far Eastern district, chronically underdeveloped and thereby a lack of any infrastructure, entails enormous financial supports ${ }^{1}$. Thus the expenses are hard to be covered only by the Russian governmental budget, and accordingly it is expected that the attraction of investments in abroad will determine the success of the new policy. For the successful execution of the policy, the federal government implemented practical policy mechanisms to attract investments in the Far Eastern district, comprised of Eastern Economic Forum (EEF), Advanced Special Economic Zones (ASEZs), Vladivostok Free Ports (VFPs), and Far Eastern Hectare (FEH). As the effect of those policy mechanisms, the percentage of the FDI BoP in the Far Eastern district compared by the total increased from $4.7 \%$ in 2012 to
$8.4 \%$ in 2016 [1]. And the Far Eastern district became the $3^{\text {rd }}$ destination for the FDI among of 8 federal districts in Russia. However, despite the positive propensity, the FDI inflows in the Far Eastern district is far behind that in the Central Federal district. In 2017, $67.8 \%$ of the total FDI flew in the Central Federal district, while $6.8 \%$ in the Far Eastern district [2]. Thereby, constructing the investment conducive environment should be done in the first place.

By reflecting the importance of inducing the FDI, in this paper, as a means to measuring the FDI attractiveness, and identifying the factors, eluding FDI inflows, we analyzed the FDI attractiveness of the Russian Far East by Porter's Diamond Model consisting of four endogenous factors - factor condition, demand condition, related and supporting industries, and firm strategy, structure, and rivalry- and two exogenous factors - chance and government policy. The secondary data used for the analysis were collected from diverse sources by the followings: the websites of Far East Development Corporation (FEDC), EEF, and FEH.

Han-Sol Lee - Graduate Student, hanso1900217@gmail.com

${ }^{1}$ The Russian Federation, the largest country in the world by covering one-eight of the total landmass, is composed of the eight federal districts: Central, Northwestern, Southern, North Caucasian, Volga, Ural, Siberian and Far Eastern. Inter alia, Far Eastern District is the biggest by accounting $35 \%$ of the total landmass of Russian Federation. However, this area is among of the least developed because of harsh climate and poor infrastructure. In 2016, the Gross Regional Product (GRP) of the Far Eastern District was 3,757 billion Russian Rubles, accounting $5 \%$ of the Russian GDP. This is the second lowest level amongst federal districts (The Russian Federal State Statistics Service, 2018). 


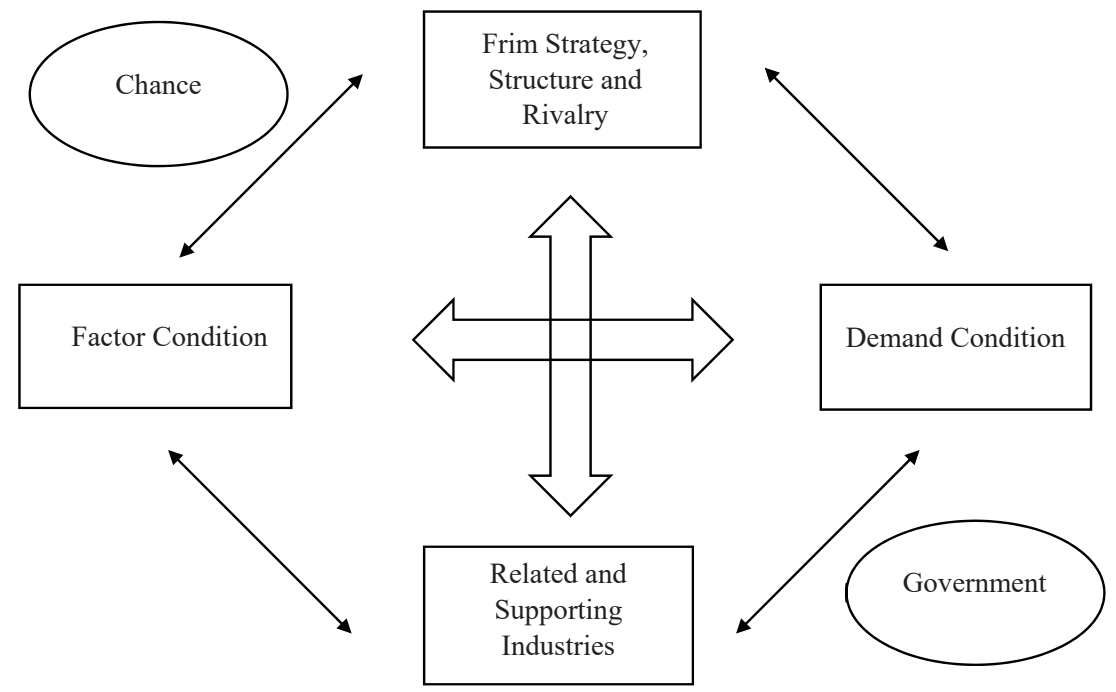

Fig. 1. Porter's Diamond model [13]

\section{Literature Review on FDI Determinants Factors in the Developing Economy}

A plethora of studies on the FDI determinants factors in the developing economies was conducted, but there were no factors commonly applied to all developing economies [3]. Depending on the research area, the previous studies opined different FDI determinant factors [4]. Some studies on the European transition economies elucidated that the positive relation of EU membership and political stability, while the negative relation of a pervasive corruption with the FDI inflows [5-7]. On the other hand, other studies on the investments on the $\mathrm{BRIC}(\mathrm{S})$ demonstrated that those are majorly marketing-seeking investments, and thereby, economic factors, for instance, market size, trade openness, capital (infrastructure), and favorable investment climate, significantly determine the FDI inflows [8-10]. In addition, the recent studies found out that the factors related to the technology, such as innovation, a guarantee of technology ownership, FDI policies in science, positively induce the FDI [11-12].

\section{Porter's Diamond Model (1990)}

The Diamond Model was introduced by Michael Porter in 1990 in his book under the title of "Theory of National Competitiveness Analysis". According to the theory, four endogenous factors-factor condition, demand condition, related and supporting industries, and firm strategy, structure, and rivalry- and two exogenous factors - chance and government - critically determine the national competitiveness (Fig. 1).

Factor conditions are the presence of factors for the production. It is composed of basic factors and advanced factors. Basic factors are for instance labor, land, natural resources, and infrastructure. Advanced factors are R\&D costs, skilled labors, high technology, scientific bases, knowledge-intensive industries, and so forth (Tabl. 1).

Demand factors measure the demand of the domestic market on a certain industry's product. Those factors include, for instance, GDP per capita, GDP growth rate, PPP, and disposable income. Besides, the diamond model considered the qualitative aspects of the demand. For an example, Swish's particular taste on a watch contributed to developing the watch industry in Switzerland, while Japanese high knowledge on electronics led the development of the electronics industries in Japan.

Related and supporting industries are the level of the vertical and horizontal relevance amongst the industries, measured by, such as clusters and infrastructures. The accumulation of the relevant industries will create synergy effects between suppliers and consumers, and amongst suppliers by facilitating the access each other.

Firm strategy, structure, and rivalry is how the companies are created, managed, and operated and as well as the intensity of the rivalry in the domestic market. Companies' strategies and organizational structures in accordance with the certain characteristics of the domestic industry can serve as a competitive advantage in the global market. Especially, strong competitors in the same industries stimulate the innovation demands of enterprises.

Besides the above four endogenous factors, government can exert an influence on competitiveness through policies. Government policies have an effect on endogenous factors ambiguously. The effect of new policies can act as both positives and negatives on the endogenous factors [13].

Chance is incidents occurred outside the nation. It is totally apart from the control by the nation. But, it can influence on the national competitiveness as either a luck or a catastrophe. 


\begin{tabular}{|c|c|c|}
\hline \multirow{2}{*}{\multicolumn{3}{|c|}{ The factor condition of the Far Eastern district }} \\
\hline & & \\
\hline \multirow{3}{*}{ Basic Factor } & The Average Nominal Wage per Month in 2016 & 52.8 thousand rubles \\
\hline & Landmass & 6.9 million $\mathrm{km}^{2}$ \\
\hline & Population & 8.2 million \\
\hline Advanced Factor & Average $R \& D$ expenses in 2018 ( $\%$ of revenues) & $2.0 \%$ \\
\hline
\end{tabular}

\begin{tabular}{|cc|}
\hline & The demand condition of the Far Eastern district \\
\hline Gross Regional Product (GRP) in 2017 & $3,878,320$ million rubles \\
GRP Growth Rate (\%) in 2017 & $4.6 \%$ \\
GRP per capita in 2017 & 641 thousand rubles \\
Source: Deloitte CIS Research Center Moscow (2018), The Russian Federal State Statistics Service (2018). &
\end{tabular}

\author{
The related and supporting industries of the Far Eastern district \\ Number of Special Economic Zones (SEZs) \\ Number of Free Ports (FPs) \\ Number of Industrial Clusters
}

18
22
0

Table 3

Source: Far East Development Corporation (2018b; 2018c), The Ministry of Industry and Trade of Russia (2019).

\section{An Analysis of Russian Far East's FDI attractiveness by Porter's Diamond Model}

For the factor conditions, 3 basics factors-the average nominal wage per month, landmass, and population-, and 1 advanced factor were considered. The average wage of the Far East is rather high given that the average nominal wage per month in 2016 was 52.8 thousand rubles, $24 \%$ above the Russian average. The landmass of the Far Eastern District is the biggest amongst 8 Russian federal districts, accounted for approximately $40 \%$ of the whole country. On the other hand, the population is only 8.2 million, accounted for $5.6 \%$ of the total, despite the biggest district landmasswise. Considering the advanced factor, the average R\&D expenses (\% of revenues) in 2018 of the Far Eastern district was lower than the other regions of Russia: the former marked $2.0 \%$, while the latter was $3.7 \%$. Thereby, we could say that the R\&D expenditure of the government and companies in the Far East is rather minimal compared by average Russia [14].

In terms of the demand condition (Tabl. 2), 3 factors are analyzed: GRP, GRP rate, and GRP per capita in 2017. The GRP of the Far East is 3,878 billion rubles, accounted for only $5.5 \%$ of the national total. However, in terms of the growth rate, the Far East growth rate in 2017 marked $4.6 \%$, more than 3 times the national growth rate, which was $1.5 \%$ in 2017 . The GRP per capita in the Far East, 641 thousand million rubles, is less than the national average, 10,743 us dollars, approximately 700 thousand million rubles (see Tabl. 2) [15].

The related and supporting industries are crucial to induce investments by creating cluster effects. To measure this factor, in this study, we considered the number of SEZs, FPs and industrial clusters. The purpose of SEZs is to build the production-base by creating a certain industrial cluster in each zone, while the FPs are promoted to be utilized as a logistic-hub. Thereby, by locating SEZs and FPs nearby, those areas can generate synergy-effects. While an industrial cluster by locating similar complex of business nearby can create high efficiency [16].

In 2015, throughout the Far Eastern District, the federal government designated the 18 areas as the ASEZs, and 22 districts as the VFPs in accordance with the federal law No. 473, and the federal law No. 212, respectively. The enterprises will enter in those areas and districts, benefiting from, for instance, de-administration, tax sop, infrastructure, consultations, and so forth (Tabl. 3) [17].

According to the Ministry of Industry and Trade of Russia (2019), there are 29 industrial clusters in Russian Federation as a whole. Those industrial clusters are located at 6 out of 8 federal districts: Volga Federal District (11), Central Federal District (9), Northwestern Federal District (4), Siberian Federal District (4), Ural Federal District (1), and North Caucasian Federal District (1). There is no even single cluster in the Far Eastern Federal District by the end of 2018. However, following the Investment Website of the Far Eastern Federal District (2019), cluster projects, for instance gas processing cluster and the iron ore processing cluster, are under the preparation for the near future [18].

By looking at the FDI BoP, we can evaluate whether the Far East effectively adopted the strategies on making the conducive environments for investors. In 2017, FDI Bop of the Far East was 8,157 million us dollars, the third out of the eight districts. From that, we can say that, despite, the low population density, which is the factor reduce the attractiveness in terms of the low demand, the Far East well induces the investments. Besides, in terms of financial optimism, the index measuring the financial environment, the Far East marked 0.28, which is the country's average. In terms of standard of investment attractiveness, allowing unified and simplified business executions, in 2015, 4 out of 9 federal subjects fulfilled 
The firm strategy structure and rivalry of the Far Eastern district

FDI BoP of the Far East in 2017

Financial Optimism in 2018

The Number of federal subjects fulfilling Regional standard of investment attractiveness in $2015^{2,3}$

Source: Investment Website of the Far Eastern Federal District (2015), Deloitte CIS Research Center Moscow (2018), The Central Bank of the

Russian Federation (2018).

all 15 requirements concerning the strategy of region, conditions for business, and investment guarantees of the standard. Among of the other rest of federal subjects, only excluding the Jewish Autonomous Oblast (8), all of them implemented 11-14 requirements (Tabl. 4) [16-19].

\section{The chance of the Far Eastern district}

The eco-political environmental changes in the major Asia Pacific countries could contribute to increasing the FDI in the Russian Far East, despite some risky points. Since 2013, China has sought the policy initiative - "One Belt One Road (OBOR)" - for seeking the stable provision of the energy and resource, and by signing Memorandum of Understandings (MOUs) with Russia, the Russian Far East is reckoned as one of the focal regions for the Chinese investments [20]. However, in a sense that, historically, the Russian Far East has been threatened by the Chinese expansion, the massive Chinese investments inflows in the region still hold some risks. Besides on that, as a means to overcoming the high economic dependence on USA and China by cooperating with the Northern countries, in 2017, South Korean government under President Moon Jae-In addressed

${ }^{2}$ The Far Eastern Federal District is composed of nine federal subjects: Chukotka Autonomous Okrug, the Sakha Republic (Yakutia), Amur Oblast, Khabarovsk Krai, Primorsky Krai, the Jewish Autonomous Oblast, Sakhalin Oblast, Magadan Oblast, and Kamchatka Krai (Investment Website of the Far Eastern Federal District, 2015).

${ }^{3}$ The standard of investments attractiveness is comprised of the following 15 requirements: "Strategy of region-creation of regional investment strategy by government agencies, creative planning of investment infrastructure objects, and annual report of the head of administration of Russian region <investment climate and strategy of region in Russian Federation>; Conditions for business-investors protection laws and enabling mechanism for investment activity, investment climate improvement council, special organization which attracts investments and work with investors, infrastructure for distribution of investment projects, retraining courses in sphere of the most useful specialties by investors, special web-site, and consistent system of supporting projects (one stop principle); investment guarantees-regional investment declaration, law on regulations and standards with concern an entrepreneurship, and retraining courses for stuff which working on the investment attraction, integration in regional energy system more than 3 members from primal groups of commercial customers, and direct links between investors and regional administrators" (Investment Website of the Far Eastern Federal District, 2015).

${ }^{4}$ The Presidential Committee on Northern Economic Cooperation, http://bukbang.go.kr
"New Northern Policy", and established the Presidential Committee on Northern Economic Cooperation ${ }^{4}$. Unlike the Chinese investments, South Korean investments are not risky, but rather has a possibility to create the win-win effects by paving the way for the tri-angular economic cooperation between South and North Korea and Russia, as reflecting the current improved inter-Korean relations.

\section{The role of the government of the Far Eastern district}

To induce the inward FDI, besides ASEZs and FPs, the Russian federal government implemented other practical policy-mechanisms in accordance with the Turn to the East Policy: EEF, and FEH. The EEF- effective by Decree No. 250 of President Vladimir Putin in 2015- is an annual event, held in Vladivostok, established to promote the FDI inflows in the Far East (Roscongress Foundation, n.d.). In $2018,6,000$ people-including 1,357 journalistsfrom 60 countries participated in the forum, and 220 Memorandum of Understandings (MOUs) - amounted approximately 3.108 trillion rubles- are concluded [21]. In addition, to resolve the continuous population outflows of the Far East, in 2016, Far Eastern Hectare (FEH) by the law No. $119 \mathrm{FL}$ was enacted for the provision of a free 1-hectare land plot for whom migrates to the Far East (Ministry for the Development of the Russian Far East, n.d.) [22].

\section{Conclusion}

In this study, we examined the FDI attractiveness of the Russian Far East by reflecting the growing importance of the region due to the federal government's new policy: Turn to the East. From the study, we draw the following conclusions.

First, the Far East holds relatively weak factor and demand conditions in terms of the high wage, low population density despite the vast landmass, low investments on R\&D, and the low GRP. Those factors decrease the attractiveness of the investments given that the market size is too small accompanying with the low purchasing power.

Second, despite the poor factor and demand conditions, the future forecast on the FDI environments of the Far East is bright by being marked positively on the other Porter's Diamond factors - the related and supporting industries, the firm strategy structure and rivalry, chance and the role of government. We found that the federal government adopted the diverse policy mechanisms to build the FDI conducive environments, such like; ASEZs, VFPs, EEC and FEH. Besides on that, the political interests of the East Asian countries- China's 
"One Belt One Road (OBOR)" and South Korea's New Northern Policy - provide chances to the Far East to induce investments. However, in respect with South Korea could generate win-win effects, while Chinese investments hold risk of the Chinese Expansionism, we can say that, for Russia, South Korea is the safer option for the economic cooperation in the Far East.

Thereby, to foment the Far East as the attractive FDI destination, by practically utilizing the current policy mechanisms to increase the basic factor and demand conditions in a better manner to actualize the bright forecast in a real. On the other hand, despite the comprehensive policy implementations to induce the inward FDI to the Far Eastern District by constructing FDI conducive environments, the outcome yet did not reach to the significant level. The Far Eastern district is still barren to commence business in terms of production and demand factors by failing to deriving visible fruits.

It is certain that the importance of the eastern part of Russia is being emphasized compared to before publicizing the Turn to the East policy in 2012. However, Russia's foreign policy is still focused on post-soviet, European, and Middle East countries (Buy Russia 21, 2019). Despite the rising interest in the Far East driven by economic factors, due to the low political will, the implementation of the policy is not enough fostered. There still remains considerable sceptics on the issue of the Far Eastern development amongst domestic policy makers due to the enormous government budget required with high risks [23]. Therefore, it should be stressed that to increase the efficiency of the implemented policy mechanisms and speed up the Turn to the East policy, the strong political must be accompanied.

\section{References}

1. The Russian Federal State Statistics Service (2018). Gross regional product by constituent entities of the Russian Federation, 1998-2016. Available at: http:// www.gks.ru/free_doc/new_site/vvp/vrp98-16.xIsx (accessed: 18.10.2018). (In Russ.)

2. The Central Bank of Russian Federation. 2018. Inward Direct Investment in the Russian Federation by Region of Resident's Registration. Available at: www.cbr.ru/vfs/eng/statistics/credit_statistics/ direct_investment/dir-inv_reg-in_e.xIsx (accessed: 20.10.2018). (In Russ.)

3. Chernikov S.Yu. Features of Russian companies expansion to Chinese markets. Vestnik Moskovskoi mezhdunarodnoi vysshei shkoly biznesa MIRBIS = Bulletin of the Moscow International Higher School of Business MIRBIS. 2016. No. 1. Pp. 44-46. (In Russ.)

4. Iloie R.E. Connections between FDI, corruption index and country risk assessments in Central and Eastern Europe. Procedia Economics and Finance. 2015. Vol. 32. Pp. 626-633. DOI: 10.1016/S2212-5671(15)01442-2

5. Bevan A.A., Estrin S. The determinants of foreign direct investment into European transition economies. Journal of Comparative Economics. 2004. Vol. 32. No. 4. Pp. 775-787. DOI: 10.1016/j.jce.2004.08.006
6. Brada J.C., Kutan A.M., Yigit T.M. The effects of transition and political instability on foreign direct investment inflows: Central Europe and the Balkans. Economics of Transition. 2006. Vol. 14. No. 4. Pp. 649680. DOI: $10.1111 /$ j.1468-0351.2006.00272.x

7. Cuervo-Cazurra A. Better the devil you don't know: Types of corruption and FDI in transition economies. Journal of International Management. 2008. Vol. 14. No. 1. Pp. 12-27. DOI: 10.1016/j.intman.2007.02.003

8. Narayanamoorthy V., Sridharan P., Rao K. Determinants of FDI in BRICS Countries: A panel analysis. International Journal of Business Sciences and Applied Management. 2010. Vol. 5. No. 3. Pp. 1-13.

9. Gasanova A., Medvedev A.N., Komotskiy E.I. The assessment of corruption impact on the inflow of foreign direct investment. Applied Mathematics and Computer Science: Proceedings of the 1st International Conference on Applied Mathematics and Computer Science. Vol. 1836. Rome: American Institute of Physics Inc., 2017. DOI: 10.1063/1.4981951

10. Asongu S., Akpan U.S., Isihak S.R. Determinants of foreign direct investment in fast-growing economies: evidence from the BRICS and MINT countries. Financial Innovation. 2018. Vol. 4. P. 26. DOI: 10.1186/s40854018-0114-0

11. Guimón J., Chaminade C., Maggi C., SalazarElena J.C. Policies to attract R\&D-related FDI in small emerging countries: Aligning incentives with local linkages and absorptive capacities in Chile. Journal of International Management. 2018. Vol. 24, No. 2. Pp. 165178. DOI: $10.1016 / j . i n t m a n .2017 .09 .005$

12. Kayalvizhi P.N., Thenmozhi M. Does quality of innovation, culture and governance drive FDI?: Evidence from emerging markets. Emerging Markets Review. 2018. Vol. 34. Pp. 175-191. DOI: 10.1016/j. ememar.2017.11.007

13. Porter M.E. The Competitive Advantage of Nations. Harvard Business Review, 1990. Vol. 68. No. 2. Pp. 73-93.

14. Deloitte CIS Research Center Moscow. 2018. Business and Financial Climate in the Far Eastern region. Available at: https://www2.deloitte.com/content/dam/ Deloitte/ru/Documents/research-center/far-easternfederal-district.pdf (accessed: 18.10.2018).

15. Far East Development Corporation. About Far East. 2018a. Available at: https://erdc.ru/en/about-fareast/ (accessed: 08.04.2018).

16. Investment Website of the Far Eastern Federal District. Investment platforms. 2019. Available at: https:// invest.minvr.ru/en/pages/29 (accessed: 01.05.2019).

17. Far East Development Corporation. 2018b. ASEZ (Advanced Special Economic Zone). Available at: https://erdc.ru/en/about-tor/ (accessed: 10.12.2018).

18. Far East Development Corporation. 2018c. FPV (Free Port of Vladivostok). Available at: https://erdc.ru/ en/about-spv/ (accessed: 10.12.2018).

19. The Ministry of Industry and Trade of Russia. 2019. Statistical information summary on the Geographical Information System for clusters. Available at: https://www.gisip.ru/stats_sum_clusters/pdf/en/ (accessed: 01.05.2019). 
20. Eastern Economic Forum. About the Eastern Economic Forum. Available at: https://forumvostok.ru/ en/about-the-forum/ (accessed: 18.01.2019).

21. Eastern Economic Forum. Outcomes of the Eastern Economic Forum 2018. Available at: https:// forumvostok.ru/en/news/itogi-raboty-vostochnogoekonomicheskogo-foruma-2018/ (accessed: 18.12.2019).
22. Ministry for the Development of the Russian Far East. Far Eastern Hectare. Available at: https:// eng.minvr.ru/activity/razvitie-msp-i-konkurentsii/ dalnevostochnyy-gektar/ (accessed: 10.12.2018).

23. Blakkisrud H. An Asian Pivot Starts at Home: The Russian Far East in Russian Regional Policy. In: Russia's Turn to the East. Global Reordering. Cham (Switzerland): Palgrave Pivot, 2018. Pp. 11-30. DOI: 10.1007/978-3319-69790-1_2

Ekonomika $v$ promyshlennosti $=$ Russian Journal of Industrial Economics

2019, vol. 12, no. 3, pp. 334-340

ISSN 2072-1633 (print)

ISSN 2413-662X (online)

\section{Анализ привлекательности прямых иностранных инвестиций российского Дальнего Востока по алмазной модели Портера}

Хан Сол Ли - аспирант кафедры маркетинга, hansol900217@gmail.com

Российский университет дружбы народов, 117198, Москва, ул. Миклухо Маклая, д. 6.

Аннотация. Статья посвящена оценке привлекательности прямых иностранных инвестиций (ПИИ) на российском Дальнем Востоке.

В 2012 году Российская Федерация официально обратилась к Политике «Поворот на Восток» через «Меры по реализации внешней политики Российской Федерации» для разрешения хронически слаборазвитой экономики Дальневосточного округа. Развитие Дальнего Востока нацелено на привлечение огромных инвестиций из-за рубежа под масштабные инвестиционные проекты. Однако, несмотря на постоянно растущую потребность в инвестициях на российском Дальнем Востоке, результат пока не впечатляет. Это требует проведения тщательного анализа привлекательности прямых иностранных инвестиций (ПИИ) на Дальнем Востоке. В этом исследовании автор проанализировал привлекательность данного вида вложений на Дальнем Востоке на основе алмазной модели Портера, состоящей из четырех эндогенных факторов: фактора производства, фактора спроса, смежных и вспомогательных отраслей, структуры устойчивой стратегии и соперничества, а также двух экзогенных факторов. и правительство. На основе анализа автор выявил наиболее слабый фактор и определил, что существующие условия и неоднозначная государственная политика является главным препятствием для ускорения политики «Поворот на Восток». Таким образом, мы пришли к выводу, что для достижения необходимого импульса требуется достижение более высокой эффективности политических механизмов стимуляции ПИИ.

Ключевые слова: прямые иностранные инвестиции (ПИИ), политика России на Востоке, экономи- ка России, экономика Азиатско-Тихоокеанского региона, экономика Евразии, алмазная модель Портера

\section{Библиографический список}

1. Валовой региональный продукт по субъектам Российской Федерации в 1998-2016 гг. URL: http:// www.gks.ru/free_doc/new_site/vvp/vrp98-16.xlsx (дата обращения: $18 . \overline{10}$ 10.2018).

2. Центральный банк Российской Федерации (2018). Прямые иностранные инвестиции в Российской Федерации по регионам регистрации резидентов. URL www.cbr.ru/vfs/eng/statistics/credit statistics/direct_investment/dir-inv_reg-in_e.xlsx (дата обращения: 20.10.2018).

3. Черников С.Ю. Особенности экспансии российских компаний на рынки Китая // Вестник Московской международной высшей школы бизнеса МИРБИС. 2016. № 1(5). C. 44-46.

4. Iloie R.E. Connections between FDI, corruption index and country risk assessments in Central and Eastern Europe // Procedia Economics and Finance. 2015. V. 32. P. 626-633. DOI: 10.1016/S22125671(15)01442-2

5. Bevan A.A., Estrin S. The determinants of foreign direct investment into European transition economies // Journal of Comparative Economics. 2004. Vol. 32, N 4. P. 775-787. DOI: 10.1016/j.jce.2004.08.006

6. Brada J.C., Kutan A.M., Yigit T.M. The effects of transition and political instability on foreign direct investment inflows: Central Europe and the Balkans // Economics of Transition. 2006. V. 14. N 4. P. 649-680. DOI: 10.1111/j.1468-0351.2006.00272.x

7. Cuervo-Cazurra A. Better the devil you don't know: Types of corruption and FDI in transition economies // Journal of International Management. 2008. V. 14. N 1. P. 12-27. DOI: 10.1016/j.intman.2007.02.003

8. Narayanamoorthy $V$., Sridharan P., Rao K. Determinants of FDI in BRICS Countries: A panel analysis // International Journal of Business Sciences and Applied Management. 2010. V. 5. Iss. 3. P. 1-13.

9. Gasanova A., Medvedev A.N., \& Komotskiy E.I. The assessment of corruption impact on the inflow of 
foreign direct investment // Applied Mathematics and Computer Science: Proceedings of the 1st International Conference on Applied Mathematics and Computer Science. Vol. 1836. Rome: American Institute of Physics Inc., 2017. DOI: 10.1063/1.4981951

10. Asongu S., Akpan U.S., Isihak S.R. Determinants of foreign direct investment in fast-growing economies: evidence from the BRICS and MINT countries // Financial Innovation. 2018. V. 4. P. 26. DOI: 10.1186/s40854-0180114-0

11. Guimón J., Chaminade C., Maggi C., Salazar-Elena J.C. Policies to attract R\&D-related FDI in small emerging countries: Aligning incentives with local linkages and absorptive capacities in Chile // Journal of International Management. 2018. V. 24. Iss. 2. P. 165-178. DOI: 10.1016/j.intman.2017.09.005

12. Kayalvizhi P.N., Thenmozhi M. Does quality of innovation, culture and governance drive FDI?: Evidence from emerging markets // Emerging Markets Review. 2018. V. 34. P. 175-191. DOI: 10.1016/j. ememar.2017.11.007

13. Porter M.E. The Competitive Advantage of Nations // Harvard business review. 1990. V. 68. N 2. P. 73-93.

14. Deloitte CIS Research Center Moscow. 2018. Business and Financial Climate in the Far Eastern region. URL: https://www2.deloitte.com/content/dam/Deloitte/ ru/Documents/research-center/far-eastern-federaldistrict.pdf (дата обращения: 18.10.2018).

15. Far East Development Corporation. About Far East. 2018a. URL: https://erdc.ru/en/about-far-east/ (дата обращения: 08.04.2018).
16. Investment Website of the Far Eastern Federal District. Investment platforms. 2019. URL: https://invest. minvr.ru/en/pages/29 (дата обращения: 01.05.2019).

17. Far East Development Corporation. 2018b. ASEZ (Advanced Special Economic Zone). URL: https:// erdc.ru/en/about-tor/ (дата обращения: 10.12.2018).

18. Far East Development Corporation. 2018c. FPV (Free Port of Vladivostok). URL: https://erdc.ru/en/ about-spv/ (дата обращения: 10.12.2018).

19. The Ministry of Industry and Trade of Russia. 2019. Statistical information summary on the Geographical Information System for clusters. URL: https://www.gisip.ru/stats_sum_clusters/pdf/en/ (дата обращения: 01.05.2019).

20. Eastern Economic Forum. About the Eastern Economic Forum. URL: https://forumvostok.ru/en/ about-the-forum/ (дата обращения: 18.01.2019).

21. Eastern Economic Forum. Outcomes of the Eastern Economic Forum 2018. URL: https://forumvostok.ru/en/news/itogi-raboty-vostochnogo-ekonomicheskogo-foruma-2018/ (дата обращения: 18.12.2019).

22. Ministry for the Development of the Russian Far East. Far Eastern Hectare. URL: https://eng.minvr.ru/ activity/razvitie-msp-i-konkurentsii/dalnevostochnyygektar/ (дата обращения: 10.12.2018).

23. Blakkisrud H. An Asian Pivot Starts at Home: The Russian Far East in Russian Regional Policy. In: Russia's Turn to the East. Global Reordering. Cham (Switzerland): Palgrave Pivot, 2018. P. 11-30. DOI: 10.1007/978-3319-69790-1_2 